\title{
Analysis of Macro Factors Affecting Outward Direct Investment
}

\author{
Yao Yao \\ Hangzhou Institute of Service Engineering, Hangzhou Normal University, Hangzhou, 310012, China \\ yyaoexist@163.com
}

\begin{abstract}
This paper aims to explore the macro factors which influence China's outward direct investment. This study analyzed different factors affecting outward direct investment of China. From existing research, the most prevalent macro factors include export, economic scale and exchange rate. In the empirical analysis, Brazil, India, Russia and South Africa were selected as host countries. With mixture regression model of panel data analysis, the result of empirical studies revealed that substitute effect between export and direct investment; positive correlation between economic scale and ODI; exchange rate of the currency of the host country is also significant in ODI decisions.
\end{abstract}

Keywords-Outward direct investment; Macro factors; BRICS countries

\section{INTRODUCTION}

The outward foreign direct investment (ODI) of China has been surging since the launch of the "going out" policy. The scale of ODI has been growing rapidly, while the industries and destinations of ODI have also been expanding. In 2015, the ODI from China has covered over 150counries over the world and almost all industries. This paper will examine the effects of various factors in driving this development, based on the data of ODI from China to other BRICS countries. Panel data analysis is employed in the estimation.

With the background of over competitive export market, and the pressing requirement of industrial upgrade and reform, and "the Belt and Road Initiative" strategy, the outward direct investment has increasing significance in economic growth in China, Since the economic reform and opening-up, China started to attract foreign direct investment. However, the development of outward direct investment is a much more recent issue. There are extensive studies concerning the motive and driven factors of outward direct investment. However, the outward direct investment of China has its own characteristic and unique motivation. Compared to the marginal industry transfer and cost-deduct based direct investment of developed countries, the motives of ODI from China is much more complicated.

The BRICS countries share similar economic status. Brazil, India, Russia and South Africa can provide China more opportunities in investment and other forms of economic and financial cooperation. The four host countries represent emerging economies from different continent, with various social and cultural backgrounds. Empirical studies in these countries will shed a light on the issue of outward direct investment of China.
The remainder of this paper is organized as follows: the second section analyze the macro factors which driven ODI of China; the third section illustrate the data and methodology adopted in empirical analysis; the fourth section give the results of empirical studies; the final section is conclusion remarks.

\section{IMPACT OF MACRO FACTORS ON DESTINATION SELECTION OF ODI}

The determinants driven ODI can be classified into two categories, the internal factors and external factors. The internal factors differ with individual, while the external factors includes macroeconomic output, policy and market prices, this paper mainly focuses on macro effects. The decision of an international corporation between export and direct investment relies on the factors such as exchange rates, taxes, institution, policy, export, international trade effect, etc (Blonigen, 2005). Some studies emphasis the role of government guidance in the promotion of ODI. The level of government support differs across the industries, lead to different motivation of ODI of the firms in different industries (You and Solomon, 2015). However, the most-mentioned factors include exchange rate, market size and export.

\section{A. Exchange Rate and ODI}

The exchange rate between home country and host country is an important factor in outward direct investment. Exchange rate reflects the capital cost of home country in international investment. Generally, appreciation or over valuation of one country's currency would lead to more outward foreign direct investment. The discussion concerning the relation between exchange rates and ODI has not reached a consensus. Some argue that under incomplete capital market, appreciation in the currency of home countries has positive impact in ODI (Froot and Stein, 1991). Some research indicates that currency crisis has positive influence in ODI, foreign direct investment increased in post currency crisis area, such as during and after Latin America crisis and Southeastern Asia crisis, US corporations increased their investment in the aforesaid area (Lipsey, 2001; Desai, 2004).

\section{B. Export and $O D I$}

Export from home country to host country could provide home country with political, legal, economic and cultural knowledge, which is crucial in investment. Prior connections by international trade or other forms can clear barriers for 
international investment. However, with existing international trade barriers, market-seeking motivated foreign direct investment can be a substitute for trade, to produce and sell in host countries.

The mechanism of how export and import influence ODI includes complementary effect and substitute effect. Some argue that substitute effect is more influential, hence export and ODI are negatively related. Some argue that complementary effect is the dominant effect, therefore the relation between export and ODI is positive (Johanson and Vahnle, 1997; Zhang, 2005; Quer et al, 2012). Some more recent studies examined different effects in different host country (Kang, 2012; Zhang and Huang, 2013).

\section{Economic Scale and ODI}

The motivations of outward direct investment could be nature resource seeking, cost deduction, market seeking, tax concession or to seek technology spillovers. As for developing countries, investment into host countries with healthy macroeconomic condition and rapid economic growth, could be for risk management or market seeking purposes. Hattari and Rajan (2010) examined the impact of various variables on India outward direct investment, their empirical studies show positive relation between ODI and real GDP in host country. Kolstad and Wiig (2011) studied China's outward direct investment in Africa, based on the data of 39 African countries and 4 years, they examined the relation between host country GDP and direct investment. In the decision of the destination choice, the macroeconomic status is significant factor to ODI corporations.

\section{DATA DESCRIPTION}

BRICS countries are representatives of rapidly growing emerging economies. Despite the different geographical locations and diversified cultural background, BRICS countries share similar characteristics in economic development. With the deepening of political, economic and financial cooperation in extensive aspects amongst BRICS countries, investment from China to other BRICS countries is also growing rapidly, especially in the infrastructure and other strategically important industries. To examine ODI from China to other BRICS countries, namely, Brazil, India, Russia and South
Africa, could shed some light on the macro factors affecting China's outward direct investment.

In this paper, the analysis is based on four major influential factors, export, GDP, GDP per capita and exchange rate. The international trade between BRICS countries has been surging, this paper examines relation between China's export and ODI to Brazil, India, Russia and South Africa. The macroeconomic status is an important attracting factor in foreign direct investment, in this paper, the economic scale is measured by GDP and GDP per capita of the host countries. Bilateral exchange rate, which has direct and indirect impact on investment costs, is also examined in this analysis.

The outward direct investment from China to Brazil, India, Russia and South Africa is from Statistical Bulletin of China's Outward Foreign Direct Investment, Ministry of Commerce, National Bureau of Statistics and State Administration of Foreign Exchange. The international trade data is from annual statistical report, National Bureau of statistics. The GDP and GDP per capita are from world economic outlook database, IMF. The bilateral exchange rate data is from State Administration of Foreign Exchange. All the data would be in their logarithmic form.

\section{EMPIRICAL STUDIES}

\section{A. Estimation Model}

As host countries, the macroeconomic situations of Brazil, India, Russia and South Africa have significant influence in ODI of China, the macro factors are examined to estimate their influence on ODI. Four hypotheses were brought up from previous analysis, which are as follows: hypothesis 1: the outward direct investment and export from China to country $\mathrm{j}$ has substitute effect; hypothesis 2: the outward direct investment from China to country $\mathrm{j}$ and host country's GDP is positively related; hypothesis 3: the outward direct investment from China to country $\mathrm{j}$ and host country's GDP per capita is positively related; hypothesis 4: the outward direct investment from China to country $\mathrm{j}$ and its exchange rate is negatively related.

From the analysis in section 2 , the estimation function is set as follows:

$$
\ln \left(O D I_{i}\right)=c+\beta_{1} \ln \left(E X P O R T_{i}\right)+\beta_{2} \ln \left(G D P_{i}\right)+\beta_{3} \ln \left(P G D P_{i}\right)+\beta_{4} \ln \left(\text { exch }_{i}\right)+\varepsilon
$$

In which, ODIi indicates China's outward foreign direct investment to country $i$; EXPORTi indicates China's export to country i; GDPi and PGDPi are designated to dollar form GDP and GDP per capita respectively; exchi indicate exchange rate of currency of country i.

\section{B. Results}

In exploring the impact of macro factors on ODI, panel data analysis is conducted by Eviews 8.0. The balanced panel is analyzed with mixture regression model. The result of mixture regression model passed $\mathrm{F}$ test at $99 \%$ confidence interval, which indicate good fitness of the model. While all four variables passed t rest with $95 \%$ confidence interval, which indicate significant impact of the independent variables on the dependent variable. The estimation also passed D.W. test, indicate that there was no first order

autocorrelation of random error term. The estimated equation is as follows: 


$$
\ln \left(O D I_{i}\right)=-10.8498-2.6978 \ln \left(E X P O R T_{i}\right)+3.2106 \ln \left(G D P_{i}\right)+2.5942 \ln \left(P G D P_{i}\right)-1.0809 \ln \left(\text { exch }_{i}\right)+\varepsilon
$$

With regard to the effect of macro factors on ODI, the estimation results support all of the four hypotheses. The export from China to other BRICS countries has negative effect on ODI flows, indicate that export has substitute effect on China's ODI. GDP and GDP per capita of the host countries have positive effects on the outward direct investment from China to other BRICS countries, indicate that better macroeconomic development would attract more ODI from China. Currency appreciation of the host countries has negative effect on the outward direct investment from China.

\section{CONCLUSIONS}

Outward direct investment of China has been developing rapidly. The objective of this paper is to explore the macro factors which influence China's outward direct investment. This study analyzed different factors affecting outward direct investment of China. From existing research, the most prevalent macro factors include export, economic scale and exchange rate. In the empirical analysis, Brazil, India, Russia and South Africa were selected as host countries. With mixture regression model of panel data analysis, estimation equation supported the hypotheses arise from theoretical analysis. The empirical studies revealed substitute effect between export and direct investment. Positive correlation exists between economic scale and ODI. Exchange rate of the currency of the host country is also significant in ODI decisions. To sum up, China's outward direct investment to other BRICS countries is positively related to the host country's macroeconomic development, negatively related to bilateral trade. With fastening internationalization pace of China, outward direct investment has significant importance in Chinese economy.

\section{ACKNOWLEDGEMENT}

This research was financially supported by the Natural Science Foundation of Zhejiang Province, Research on financial time series data mining, LQ15F020013.

\section{REFERENCES}

[1] L. M. Jacobs, R.V.,"Rossem, The BRIC Phantom: A comparative analysis of the BRICs as a category of rising powers", Journal of Policy Modeling, vol. 36, pp. 47-66, 2014.

[2] X. Zhang, K. Daly, "The determinants of China's outward foreign direct investment”, Emerging Markets Review, vol.12, pp. 389-398, 2011.

[3] I. Kolstad, A. Wiig, "What determines Chinese outward FDI", Journal of World Business", vol. 47, pp. 26-34, 2012.

[4] D. Herzer, "Outward FDI and economic growth", Journal of Economic Studies, vol.37, pp. 476-494, 2010.

[5] W.N.W. Azman-Saini, S.H. Law, A.H. Ahmad, "FDI and economic growth: New evidence on the role of financial markets", Economics Letters, vol.107, 2010, pp.211-213.

[6] R. Drogendijk, K. Blomkvist, "Drivers and Motives for Chinese Outward Foreign Direct Investments in Africa", Journal of African Business, vol.14,pp. 75-84, 2013.

[7] Information on http://www.stats.gov.cn

[8] Information on http://www.imf.org/external/data.htm 